\title{
Recycling Tailings Seepage Water for Diogo Heavy Minerals Mine Sustainability (Northern Senegal)
}

\author{
Mouhamat Seck $^{1,2}$, Serigne Faye ${ }^{1}$, Mark Robertson ${ }^{3}$, Michael Rose ${ }^{2}$ \\ ${ }^{1}$ Department of Geology, University Cheikh Anta Diop, Dakar, Senegal \\ ${ }^{2}$ Grande Cote Operations (GCO), Dakar, Senegal \\ ${ }^{3} \mathrm{GEO}-\mathrm{ENG}$, Queensland, Australia \\ Email: mouhamat.seck@gcosenegal.com, mouhamatseck@gmail.com
}

How to cite this paper: Seck, M., Faye, S., Robertson, M. and Rose, M. (2018) Recycling Tailings Seepage Water for Diogo Heavy Minerals Mine Sustainability (Northern Senegal). Journal of Water Resource and Protection, 10, 121-144.

https://doi.org/10.4236/jwarp.2018.101008

Received: November 30, 2017

Accepted: January 28, 2018

Published: January 31, 2018

Copyright $\odot 2018$ by authors and Scientific Research Publishing Inc. This work is licensed under the Creative Commons Attribution International License (CC BY 4.0).

http://creativecommons.org/licenses/by/4.0/

\begin{abstract}
The sandy Quaternary and the deep Maastrichtian aquifers located in the northern coastal zone of Senegal, from the locality of Kayar in the south to Saint-Louis in the north, constitute the main sources of water supply for urban and local needs as well as mining activities. The Quaternary aquifer that provides the water required for the irrigation of local farmlands, hosts a significant heavy mineral sands deposit currently being mined by the Grande Cote Operations (GCO). As a result of variable rainfall and increased water abstraction, this shallow aquifer has recorded a continuous water level decline since 1970, with potential negative effects on both the social and economic development of the region. The mining of heavy minerals (zircon, ilmenite, leucoxene and rutile) at GCO is realised through conventional dredging techniques that require large volumes of water (up to $60,000 \mathrm{~m}^{3} / \mathrm{d}$ ). The water pumped by the dredge to enable the extraction of the heavy minerals, infiltrates into the shallow aquifer, runs-off into the dredge pond or evaporates. The objective of this study is to evaluate a water balance that enables the provision of a permanent water supply to the dredge pond, whilst minimising the risk of flooding of the cropping depressions adjacent to the mine site or drying out of the farming wells. The hydrodynamic model implemented for this purpose was calibrated and tested during the first year of operation. The Root Mean Squared Error (RMSE) obtained for the calibration is approximately $0.52 \mathrm{~m}$. The predictions indicate a requirement for the system to recover part of the tailings infiltration through dewatering boreholes. The quantity of recycled water is estimated at $16,000 \mathrm{~m}^{3} / \mathrm{d}$ on average. The model simulations show an additional water requirement, extracted from the deep Maastrichtian aquifer, varying between 23,000 and $28,000 \mathrm{~m}^{3} / \mathrm{d}$ to achieve the optimum pond water level.
\end{abstract}




\section{Keywords}

Mineral Sands, Groundwater Modelling, Dredge Pond, Grande Cote Operations, Fe Flow

\section{Introduction}

Water is a key factor for most mining operations as it may be utilised in both mineral treatment processes and mining operations. With respect to heavy mineral sand mining by dredging techniques, which is of concern in this present study, groundwater resource management is a key factor for success to meet planned production rates.

The Grande Cote Operations operates in a heavy mineral sand deposit along the Senegal Northern coastal sand dunes and extracts approximately 140,000 tons of sands/day through conventional dredging techniques. The process requires permanent pumping from the dredge pond of an average $85,000 \mathrm{~m}^{3} / \mathrm{d}$ of water to transport the ore and tailings. This mining system (dredge pond and tailings) is moving through the Quaternary sand aquifer which hosts a valuable water resource for human consumption, mining and industrial needs as well as for agriculture. Towards the eastern side, the sandy aquifer extends through the Eocene limestone aquifer which provides around $115,000 \mathrm{~m}^{3} / \mathrm{d}$ of water to the National Water Supply Company (SDE) for Dakar city water consumption [1].

Water management at this mine is a real challenge in that the dredge pond must be kept at a constant level for the optimal exploitation of the deposit. This requirement presents two major risks, namely a technical risk of a lower pond water level that prevents mining progress and an environmental risk of flooding/drying out of the Niayes (interdunal depressions locally named Niayes) system which provides $60 \%$ of domestic vegetable and $80 \%$ of the horticultural export trade of Senegal [2]. These risks may lead to the closure of the mine.

Prior to mining operation commencing, a detailed hydrogeological study has been carried out in order to evaluate the system dynamic with regard to mining operations and water balance. As part of this investigation, groundwater modelling using FEFLOW code was built to achieve an operational and efficient water management system that would not restrict mining progress. Specific objectives are to:

1) Evaluate the daily volumes of water to be injected into the dredge pond to maintain optimum water levels; and,

2) Predict the hydraulic head variations in the upper aquifer to prevent flooding in the Niayes zone and hence affecting crops production.

\section{Study Area Description}

\subsection{Geography}

The study area commonly known as the Northern littoral system is located in 
the north-western part of the Senegal Sedimentary Basin. It extends between parallels $15^{\circ} \mathrm{N}$ and $16^{\circ} \mathrm{N}$, over $100 \mathrm{~km}$ in length and 30 to $35 \mathrm{~km}$ in width, representing a surface area of approximately $3000 \mathrm{~km}^{2}$ [3]. It is bounded to the west by the Atlantic Ocean, to the east by the Thiès-Saint-Louis national road, to the north by the Senegal River delta and to the south by the Thiès plateau (Figure 1). The heavy mineral sands exploited by GCO extend from Mboro, Fass Boye, Diogo to Lompoul.

Agriculture for market gardens remains the main economic activity in the study area. It represents one-third of the area under exploitation with $30 \%$ of domestic production and mobilizes $65 \%$ of the active population [4]. Water needs for this practice are pumped through wells from the shallow aquifer which depths vary between 1 and $10 \mathrm{~m}$.

In addition to agricultural activities, two major mining companies operate in this region:

- Industries Chimiques du Senegal (ICS), created in 1957 which mines the Eocene phosphate deposit and produces phosphoric acid.

- Grande Cote Operations (GCO) which mines the heavy mineral sands deposit along the dune system.

\subsection{Climate}

Climatic parameters play a fundamental role both in terms of recharge rate and evaporation losses, in relation to the groundwater. The climate of this Sahelsemi-arid region, is variable and records some changes. The climate change and variability is characterized by extreme events like highly variable rainfall, floods, droughts and sharp temperature changes. In the Northern Littoral zone of Senegal, a decrease in rainfall over the last four decades, from 1970 to 2010 ,

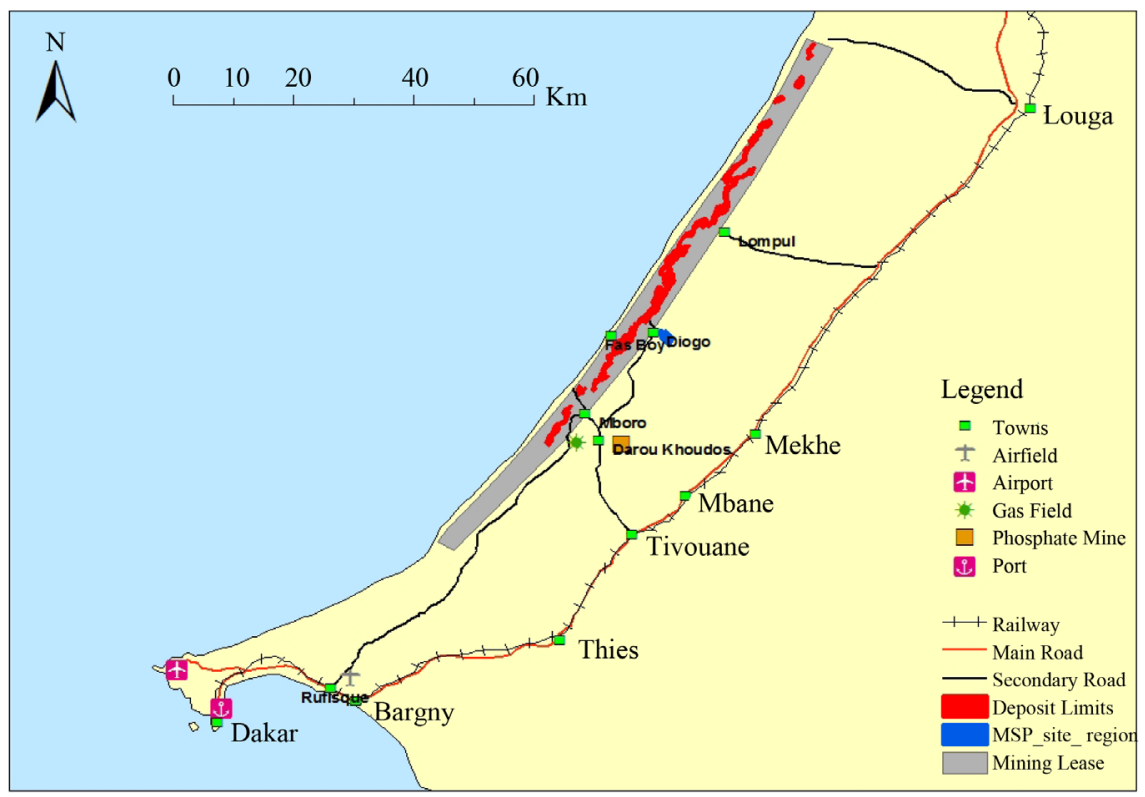

Figure 1. Map of the study area, Northern coast of Senegal. 
presents a decrease in the number of rainfall events. Across the country, recent studies on several aquifers (Senegal River Delta System, North Coast Littoral, Saloum Delta and the Casamance Delta) reveal high sensitivities to climate variability and climate change [5].

\section{Rainfall Evolution}

In the Northern Littoral zone, rainfall events generally occur between June and October (Figure 2). Rainfall quantity varies from 200 to $500 \mathrm{~mm}$ from north to south, respectively. Mean rainfall values vary from $285 \mathrm{~mm}$ at Saint Louis, 318 $\mathrm{mm}$ at Louga and $553 \mathrm{~mm}$ at Thies (Table 1). Maximum monthly rainfall occurs mainly in August or September when the intertropical front (F.I.T) reaches its extreme northern position [6].

Annual rainfall is highly variable (Table 1 ) as evidenced by the variation interval (I.V. $=1124.4 \mathrm{~mm}$ for Thiès and $723.15 \mathrm{~mm}$ for the regional average) and the inter-annual coefficient of variation which has a minimum value of 0.3 . The weighted moving average better reflects the behaviour of the rainfall regime which is characterised by a slight increase prior to 1969-1970 followed by a decrease until 1989-1990 then a slight recovery to the mean rainfall. This is characteristic of the Sahel zones where rainfall is variable from year to year.

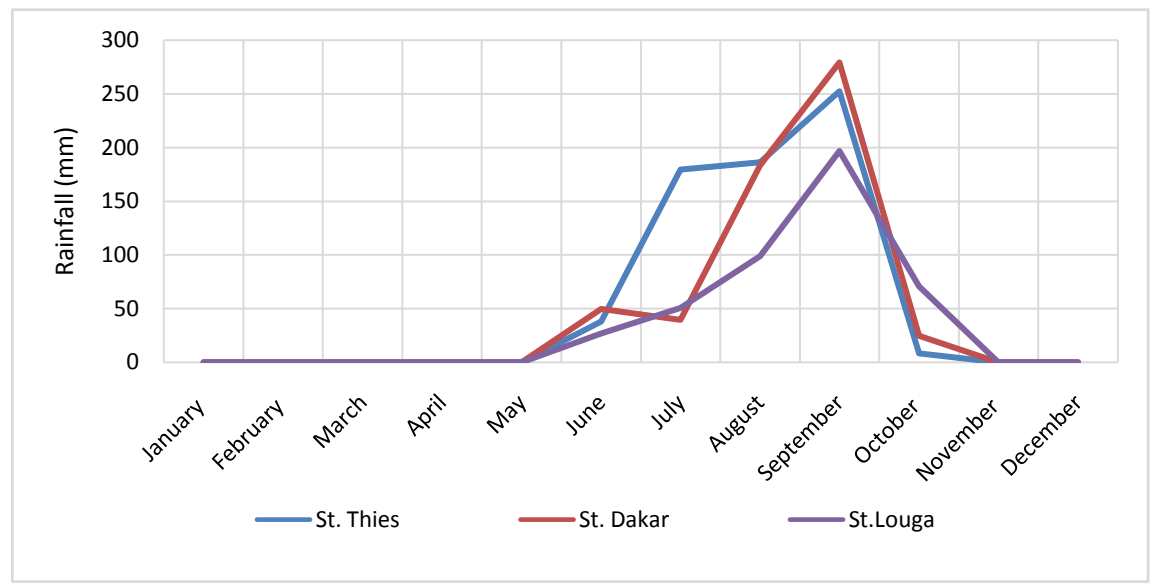

Figure 2. Monthly rainfall. Dakar, Thiès and Louga (2010).

Table 1. Statistical characteristics of annual rainfall data (1961-2011).

\begin{tabular}{cccccc}
\hline Stations & Louga & St-Louis & Thiès & Dakar & Regional \\
\hline Average $(\mathrm{mm})$ & 318.26 & 285.24 & 553.88 & 439.78 & 399.29 \\
Median $(\mathrm{mm})$ & 310.30 & 283.20 & 537.10 & 415.10 & 386.43 \\
Min $(\mathrm{mm})$ & 149.60 & 59.10 & 100.10 & 116.70 & 106.38 \\
Max (mm) & 599.00 & 593.60 & 1224.50 & 901.00 & 829.53 \\
Deviation & 106.97 & 112.20 & 204.85 & 184.94 & 152.24 \\
Coef. of variation (\%) & 33.61 & 39.34 & 36.98 & 42.05 & 38.00 \\
Coef. of asymmetry & 0.30 & 0.49 & 0.55 & 0.61 & 0.49 \\
Interv. Variation (mm) & 449.40 & 534.50 & 1124.40 & 784.30 & 723.15 \\
\hline
\end{tabular}


The weighted moving average reflects better the behaviour of rainfall. The 5year moving average curve shows a slight upward trend in above-average rainfall up to the years 1969-1970. Beyond this, it was decreasing until 2010 before recovering a slight increase while remaining close to the mean rainfall (Figure 3). The evolution of the chronic annual rainfall at these different hydrologic stations highlights the rainfall deficit that has occurred since 1972-1973.

\subsection{Other Climatic Factors}

\subsubsection{Temperature}

The average monthly temperatures recorded between 1980 and 2011 are below

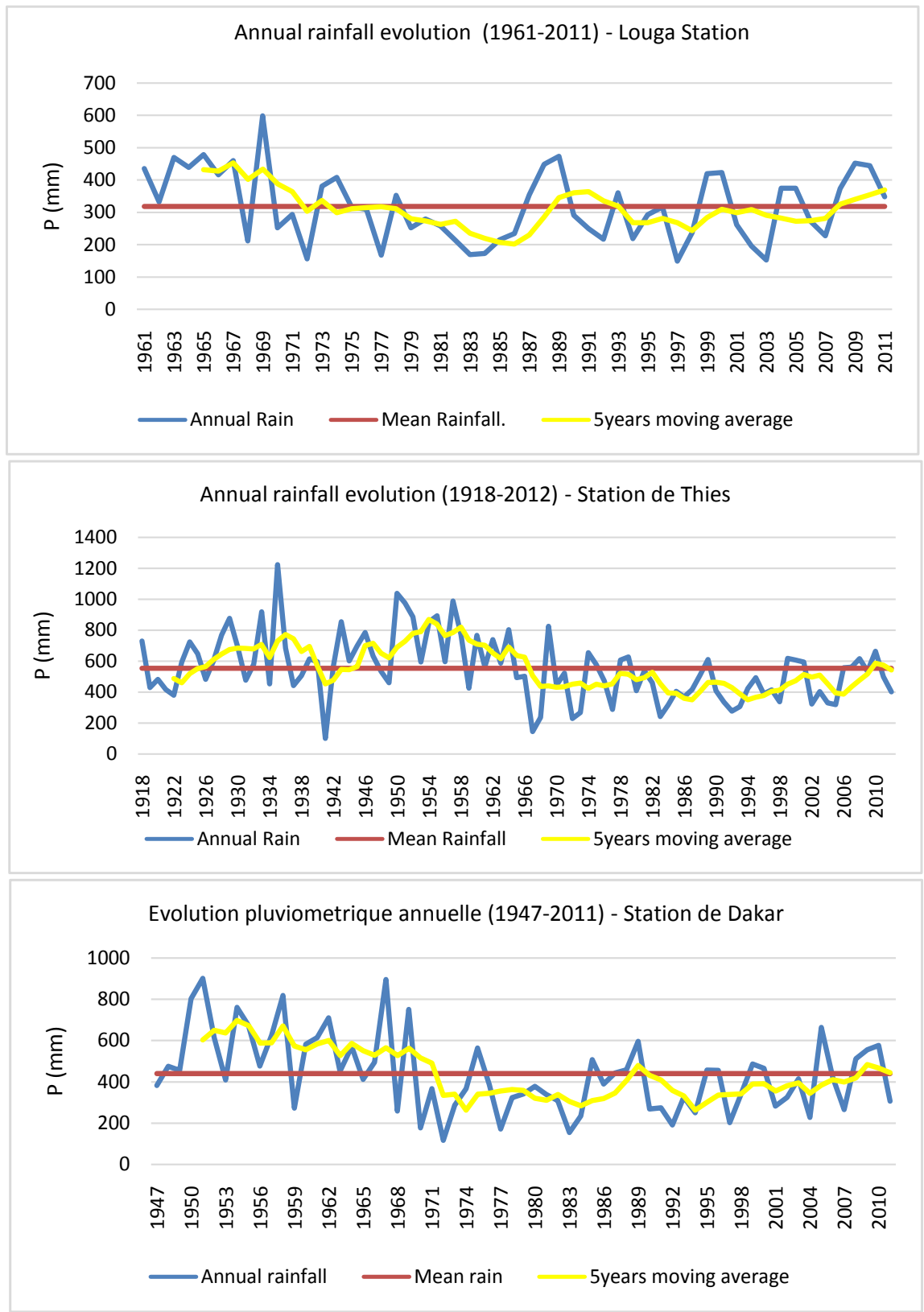

Figure 3. Annual rainfall evolution of different hydrological stations. 
$30^{\circ} \mathrm{C}$ with the exception of Louga station which peaked at $30.3^{\circ} \mathrm{C}$ in October. Monthly patterns evidenced:

- The highest monthly average temperature is between $29^{\circ} \mathrm{C}$ and $30^{\circ} \mathrm{C}$ occurring during the rainy season;

- The lowest monthly average temperature occurs during the dry season (November to May) with values ranging between $21.2^{\circ} \mathrm{C}$ and $28.8^{\circ} \mathrm{C}$.

The warmest periods generally correspond to the end of the dry season and the beginning of the rainy season with a peak occurring during October. Spatial distribution pattern shows an increase from west to east and from south to north. The amplitudes between minimum and maximum temperatures range from $5.81^{\circ} \mathrm{C}$ in January and $6.74^{\circ} \mathrm{C}$ in October.

\subsubsection{Winds}

During the dry season, the region is influenced by dry and cool NNW-SSE-continental winds (continental Alize or Harmattan); while in the rainy season (from July to October), the influence of the humid monsoon dominates.

The monthly average wind speeds measured at $2 \mathrm{~m}$ from the ground over the period 1981-2011 do not exceed $5.5 \mathrm{~m} / \mathrm{s}$. Wind patterns are intense in coastal zone such as Dakar and Saint Louis comparing to the inland zone (Thiès and Louga) with maximum value during April and minimum value in October.

\subsubsection{Relative Humidity}

The data collected at the different stations between 1981 and 2011 shows the following characteristics:

- Maximum values (88\% to $95 \%$ ) are recorded in September and minimum values (19\% to $42 \%)$ in January and February;

- The monthly relative air humidity varies from $40 \%$ in January to $83 \%$ in September.

\subsubsection{Insolation}

Data collected from Dakar, Thiès, Louga and Saint Louis stations for the period 1981-2011 show an average 8 hours of sunshine per day. Maximum values occur in April and minimum value in September and to a lesser extent in December.

\subsection{Geomorphology and Hydrography}

\section{The Geomorphology of the Dunes and Niayes Systems}

The dune system in the region comprises

- The intermediate Ogolian (corresponding to Upper Pleistocene) dune system covering an area ranging from the coastline to the interior of the land. These are dunes of the "Ogolianera", set up during the last glacial period [7].

- The outer dune system is characterized by a micro-relief which flattens towards the Senegal River mouth. It comprises three adjacent dune systems:

o Recent dunes of few to $100 \mathrm{~m}$ width are formed by the coastal drift.

o The semi-fixed yellow dunes which extent up to $3 \mathrm{~km}$ width are narrower in the South at Mbawane and Mboro [8]. These dunes bear the heavy minerals 
(ilmenite, zircon, rutile and leucoxene) deposit;

o The orange dunes derived from the reworked yellow dunes are located near the Niayes and the red dunes also contain heavy minerals.

The Niayes are interdunal depressions characterized by the presence of permanent surface water bodies corresponding to the shallow groundwater outcrop and the ancient hydrographical network [9] (Figure 4).

\subsection{Geology and Hydrogeological System}

The northern littoral system belongs to the western part of the Senegalo-mauritanian sedimentary which extends about $1400 \mathrm{~km}$ from Mauritania in the north to Guinea Bissau in the south. In the study area, the lithology is fairly well known from the Cretaceous to the Quaternary. The followings formations lay out from bottom to top:The Maastrichtian: composed mainly of sand, sandstone with calcareous and clayey layers. Along the northern littoral the top is located between 250 to $400 \mathrm{~m}$ depth. The aquifer contained in this formation is confined.

- The Palaeocene: very often separated from the Eocene by a thin layer of impervious clay is mainly composed by marl.

- The Eocene: represented by limestone and marly limestone formation is at depth between 150 and $200 \mathrm{~m}$.

- The Quaternary: the thickness is varying between 10 and $110 \mathrm{~m}$; at the Diogo deposit, the bottom is at around 50 to $60 \mathrm{~m}$. This formation consists of surface sand and deep clayey sand.

With regard to the objective of the study, we focus mainly on the Maastrichtian and Quaternary.

\subsubsection{Maastrichtian Aquifer}

In the study area, the top aquifer is approximately 420 to $460 \mathrm{~m}$ deep and the bottom is $800 \mathrm{~m}$ below sea level (mbsl). The new boreholes drilled by GCO are screened at variable depths between 430 to $530 \mathrm{~m}$ with static water levels

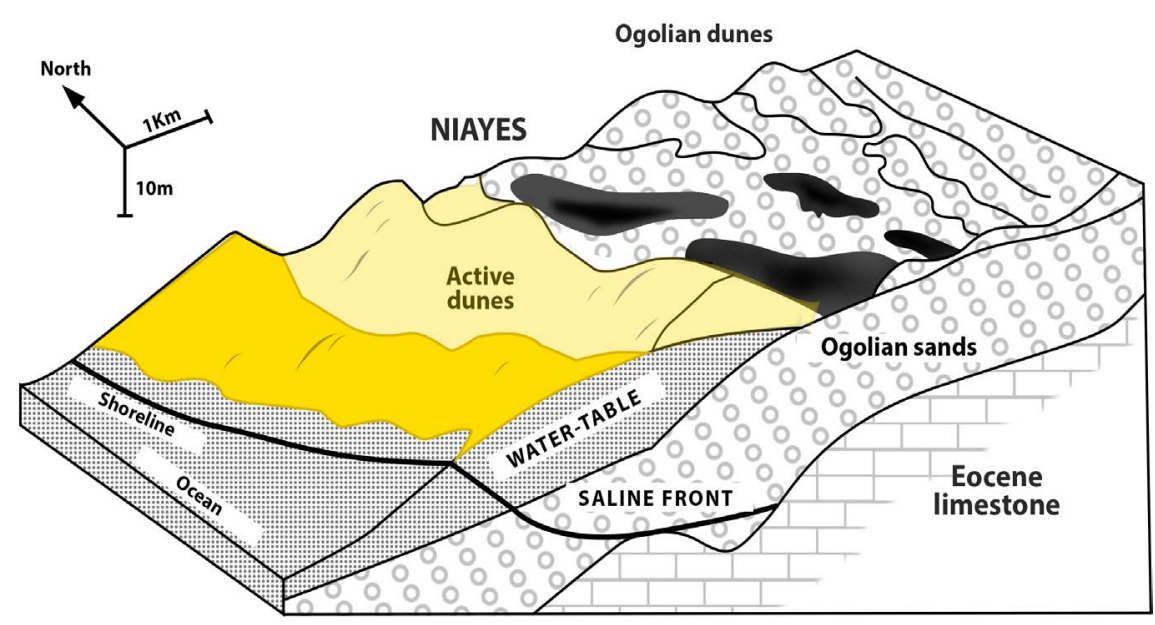

Figure 4. Schematic section of the Niayes areas modified [8]. 
between 20 to $36 \mathrm{~m}$ below ground level (mbgl). Transmissivity values range between $10^{-3}$ to $10^{-2} \mathrm{~m}^{2} / \mathrm{s}$ and bore yield varies from 1 to $3 \mathrm{~m}^{3} / \mathrm{h} / \mathrm{m}$ with a pumping yield reaching more than $200 \mathrm{~m}^{3} / \mathrm{h}$ and drawdown between 70 and $120 \mathrm{~m}$.

\subsubsection{Quaternary Aquifer}

The quaternary sediments, which consist of the two sand dune ridges, are made up of various sand textures with variable clay and silt contents with frequent occurrences of ferruginous layers and peat in the Niayes [10]. The quartz minerals are dominant; they are associated with various clays such as kaolinite, illite, montmorillonite and smectite, montmorillonite and smectite [11]. Towards the East, the karstic lutetian formation is approximately $100 \mathrm{~m}$ thick and is in contact with the quaternary sandstone formation through a fault (Figure 5).

At the Diogo deposit, GCO has drilled, 75 shallow boreholes which reveal the following layers:

- Fine to medium yellow sand with an average thickness of $3 \mathrm{~m}$ in the Niayes and up to $12 \mathrm{~m}$ in the dune areas;

- Fine to medium whitish sand, with peat of an average thickness of $15 \mathrm{~m}$;

- Medium to coarse grey quartz sand with thickness varying between $5 \mathrm{~m}$ and $10 \mathrm{~m}$;

- Clayey sand to brown sandy clay of maximum $5 \mathrm{~m}$ thickness;

- Clayey marl or marly clay between $40 \mathrm{~m}$ and $47 \mathrm{~m}$ deep; this is considered to be the bottom of the Quaternary sands aquifer in the Diogo mining area. It is reached.

\subsubsection{Hydrodynamic Functioning of the Quaternary Aquifer}

Groundwater flow in the superficial aquifer is mainly controlled by a piezometric mound located parallel to the coastal line and plunging to the north-east. Flow pattern from this mound (at $+25 \mathrm{~m}$ ) occurs in all directions with hydraulic gradient varying between $1.7 \%$ and to $3 \%$ (Figure 6). The groundwater level of the Quaternary sand aquifer has declined since 1970s [10] due to decreasing rainfall observed in the Sahel zone and continued pumping for domestic water supply. From previous studies, the water mound located at Taiba Ndiaye was at 35 masl in 1965. Compared to the current level of 25 masl, the aquifer has dropped approximately 10 meters. From 1987 to present, the water level has decreased by $2.5 \mathrm{~m}$ at Taïba and Tawa Fall (Figure 7).

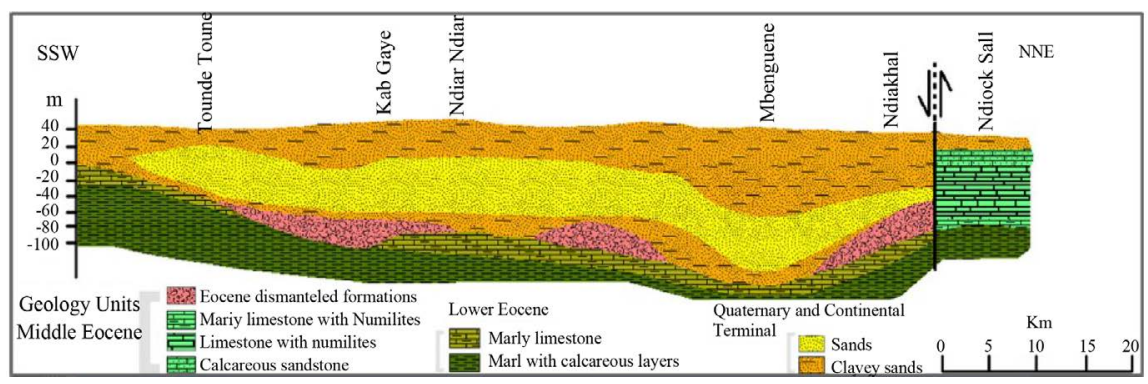

Figure 5. Geological section of the Quaternary Littoral North aquifer [9] in [10]. 
Monthly data recorded from September 2011 to July 2016 at 120 GCO piezometers exhibit seasonal fluctuations reflecting rainfall infiltration reaching the water table during November (Figure 8). Higher variations observed at all monitoring wells in 2012 correspond to the high rainfall of $630 \mathrm{~mm}$ of that year and minimum variations in 2014 reflecting lower rainfall event at Diogo during this year which is at $115 \mathrm{~mm}$. However, variation patterns $(\max 1.8 \mathrm{~m})$ exhibited at piezometers close to the mining pit imprint both tailing seepage outflow and pumping effects of the containment boreholes.

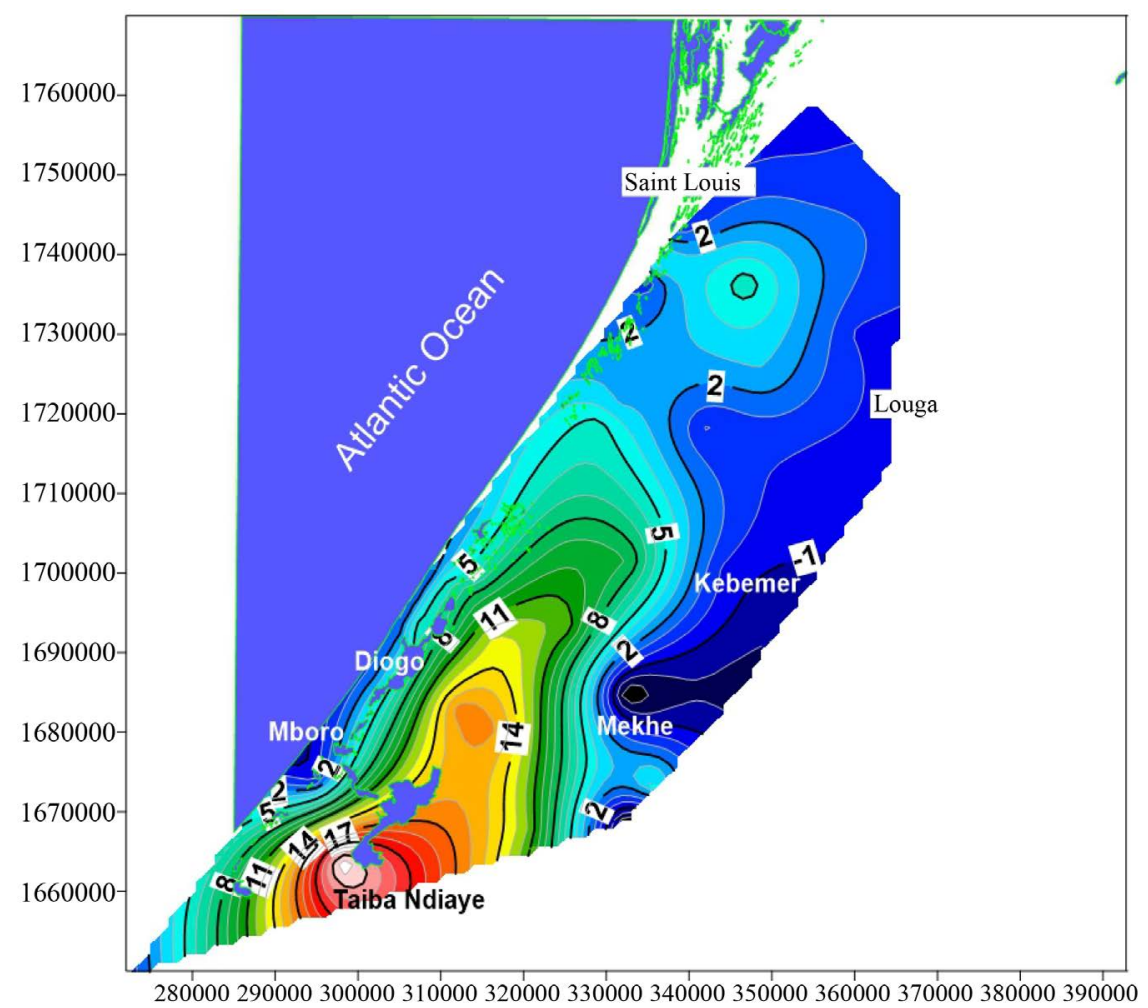

Figure 6. Contour map of the shallow aquifer in the north coast of Senegal (November 2014).

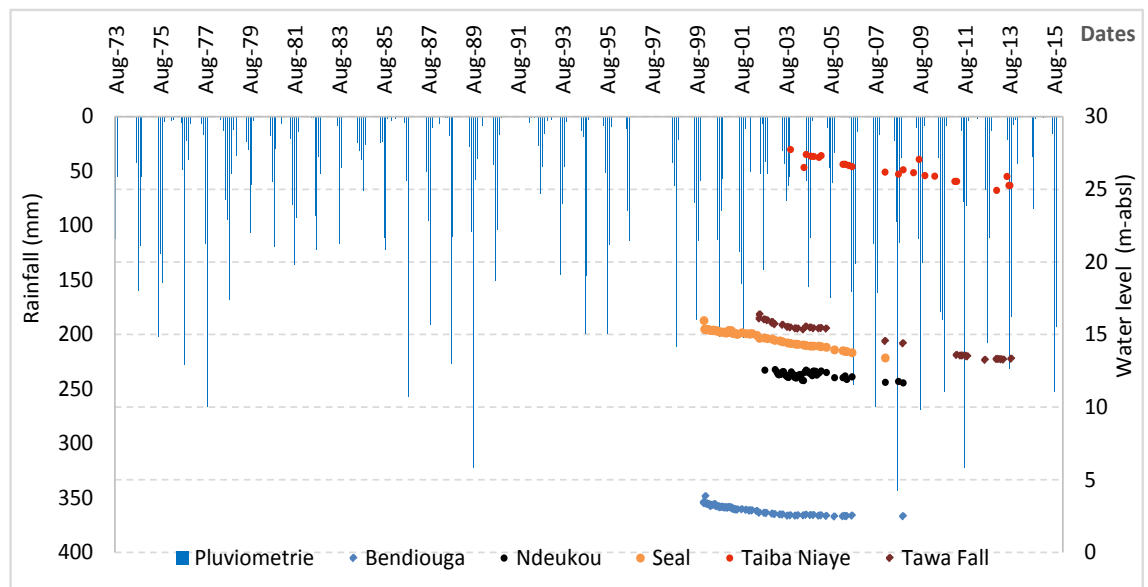

Figure 7. Piezometric level versus rainfall of the study zone between 1975 and 2015. 


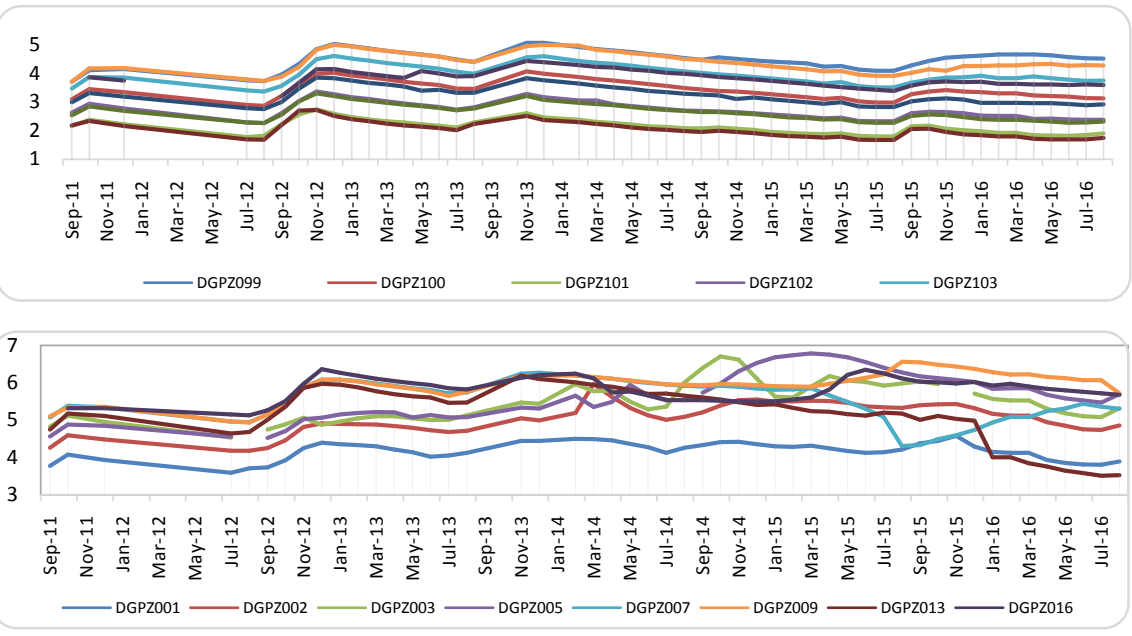

Figure 8. Piezometric variation of the Quaternary aquifer in the Diogo mining area (a North), b (South-vicinity of the dredge pond).

\subsection{GCO Miningoperation}

Grande Cote Operations (GCO) which is the world's third largest zircon mine with 7\% of world production started mining operations in this region in May 2014 between Diogo and Lompoul. The heavy mineral sands deposit mainly composed of zircon, ilmenite, leucoxene and rutile is estimated at 800 million tonnes of $1.7 \%$ heavy minerals. Mean proportions of the heavy mineral are as followed [12]:

- $85 \%$ ilmenite;

- $12 \%$ zircon;

- $1.6 \%$ leucoxene;

- $0.9 \%$ rutile.

The GCO initial mine plan is set at 55 million tons of mineralized sand per year with an average extraction rate of $7000 \mathrm{t} / \mathrm{h}$ by dredging. This mining technique consists of dredging a continuous channel, called dredge path through the dunal orebody with the dredge and the wet concentrator plant (WCP) floated on the water table. While the dredge removes the material at the front of the mine path, the tailings generated by the mineral separation process in the WCP are stacked at the back by the boom stacker and tailings lines. The tailings represent $98 \%$ of the material mined. The suction cutter dredge and the WCP progress about 15 to 30 meters per day depending on the height of the dune and the dredge pond dimensions which range between $500 \mathrm{~m}$ to $550 \mathrm{~m}$ long and between $200 \mathrm{~m}$ to $220 \mathrm{~m}$ wide (Figure 9).

The dredge operates continuously ( $24 \mathrm{hr} /$ day $\times 7$ days/week)and extracts the ore with a rotating cutter feeding a suction pump. The head cutter excavates, at an average depth of 6 meters below the pond water level. The dredge pumps the slurry to the WCP, where the mineral is separated by gravity and magnetic methods. The sand tailings are pumped and deposited directly behind the WCP where the rehabilitation of the mined area proceeds. Approximately $25 \%$ to $40 \%$ 


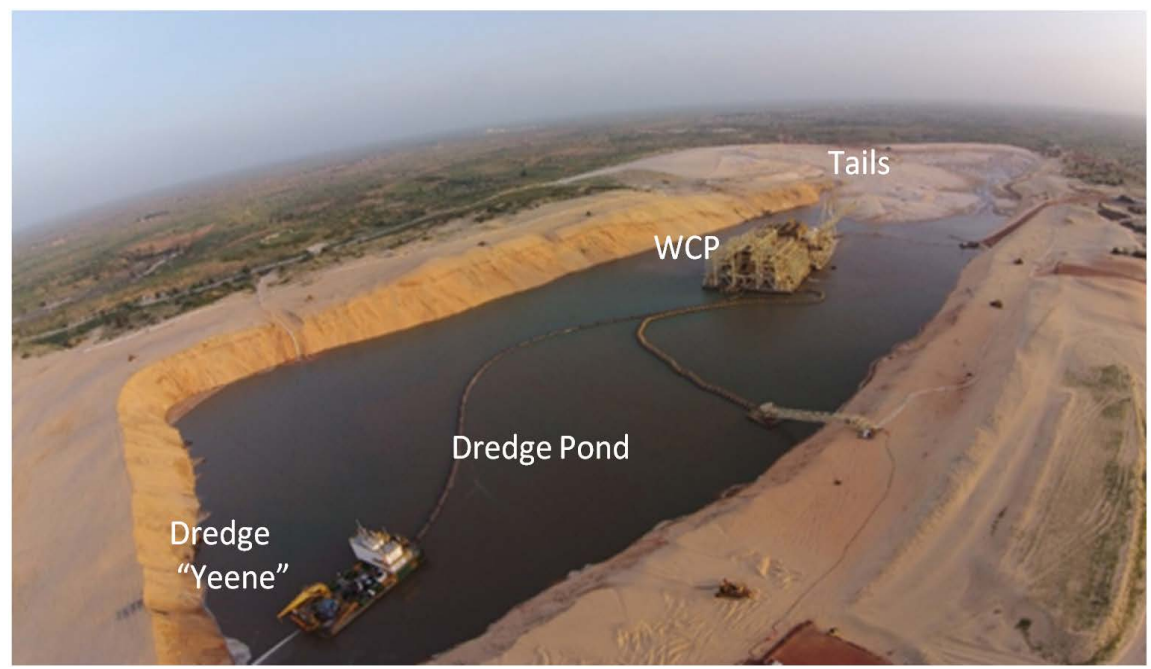

Figure 9. Aerial view of GCO dredging channel and Niayes.

of the tailings are deposited $120 \mathrm{~m}$ from the back of the pond by the boom stacker as the WCP advances. The reminder of the tailings, approximately $60 \%$ to $75 \%$ is discharged through the tailings lines at an average distance of $1 \mathrm{~km}$ behind the dredge pond.

The WCP separates the heavy mineral from the sand and pumps it to a stock pile where it is transported to the mineral separation plant (MSP) for processing into finished goods.

In order to optimize the mining rate of 7000 tph feed sand, a large quantity of water is required for ore transport in the feed line and the concentration process. The feed sand is pumped at $25 \%$ solids and the tailings are rejected at $65 \%$ solids. Water in the tailings infiltrates to the upper aquifer, evaporates, runs back to the dredge pond or seeps into the Niayes system. Prior to mining operations in 2014, the initial water level in the pond of about 6 masl was raised by 1 to $2 \mathrm{~m}$ for optimal mining. This caused a disturbance of the flow regime of the shallow aquifer where flow increases seaward and also towards the Niayes depressions. The total makeup water is approximately $2000 \mathrm{~m}^{3} / \mathrm{h}$ pumped from deep Maastrichtian boreholes for a mining rate of 7000 tph feed sand while Millennium Inorganic Chemicals mine, located in the Paraiba State of Brazil, determines $1100 \mathrm{~m}^{3} / \mathrm{h}$ makeup water required to maintain the dredge pond level against a throughput of 1650 tph [13].

As a consequence, a long-term availability of freshwater supplies to adequately address requirements over GCO mine life of 25 years is problematic in various aspects:

1) An excessive and irreversible drawdown of the Maastrichtian aquifer; and,

2) Competing water demands from the populations and ICS (pumping around 600 to $800 \mathrm{~m}^{3} / \mathrm{h}$ ).

Then, to reduce considerably the pumping from the deep aquifer, the superficial aquifer is pumped for a maximum recovery of the tailings infiltration. 


\subsection{Other Mineral Sand Mining Operations}

The majority of the mineral sand operations are using dredging method. Some of them like Millennium Minerals in the Paraiba State of Brazil are applying both methods. The dry mining technique (Excavator and trucks) is chosen for the superficial ore bodies or very high grade areas and dredging for the low grade areas. In 2002, the dredging operations had an initial throughput of 1500 $\mathrm{t} / \mathrm{hr}$. The dredge ponds were often at only a few hundred meters from the sea and were losing lots of the water pumped into the lake. To maintain the pond at natural water level, Millennium Inorganic Chemicals makeup water was 1100 $\mathrm{m}^{3} / \mathrm{h}$ [13]. To supply this volume, a pump station was generated near a close by river. The difference with GCO process is the source of makeup water. GCO makeup water is extracted from the deep Maastrichtian aquifer while Millennium is pumping from a river.

In Australia, at the mineral sand mine on north Stradbroke, CRL Company operation is based on dredging method. The pond water management includes bores and spears which are installed alongside the mine path. This, allow CRL to prevent negative impacts such as flooding of low lying areas. The dredge pond water is maintained where necessary by pumping water from fresh water swamps on the island [14]. This system of water recovery is similar with GCO expect the fact that GCO doesn't have spears. At the beginning of the mine operation, the spears option was not approved due to some physical constraints and their inefficiency in GCO context with the dredge advancing quickly about 15 to $20 \mathrm{~m} /$ day.

At Ginkgo and Snapper Mines, Cristal Mining operates two mineral sands mines in the Murray Basin. The mines are located approximately $40 \mathrm{~km}$ west of the township of Pooncarie in western New South Wales, in Australia. The dredge pond is advancing through a saline groundwater aquifer. The process includes water dams and bores given the pond water level could be raised or lowered when needed. When the dredge pond level would be raised by $14.5 \mathrm{~m}$, during the first year of mining operation, the maximum borefield water demand was around $1180 \mathrm{~m}^{3} / \mathrm{h}$ [15]. In the northern part of the deposit which is planned to be mined between Year-14 and 16, the water level would be lowered by $10 \mathrm{~m}$. For that, water would be extracted directly from the dredge pond and also by the northern borefield. The extracted water would be pumped to the water disposal dam and allowed to seep through backfilled sand residues to groundwater. The pond level rising process applied by Cristal Mining using bores is currently the same applied at GCO. For the moment, GCO doesn't need lowering the pond water level. It could be the case in the future around 2040 when the south of the release would be mined. Cristal lowering process could be an option for GCO when needed.

\section{Modelling Method}

The basic flow equation in a porous medium is as follows [16]: 


$$
\frac{\partial}{\partial x}\left(K_{x x} \frac{\partial h}{\partial x}\right)+\frac{\partial}{\partial y}\left(K_{y y} \frac{\partial h}{\partial y}\right)+\frac{\partial}{\partial z}\left(K_{z z} \frac{\partial h}{\partial z}\right)-W=S_{s} \frac{\partial h}{\partial t}
$$

With:

o $K_{x x}, K_{y y}, K_{z z}:$ Hydraulic Conductivities along $x, y$ and $z$ directions;

o $h$ : hydraulic head;

o Ss: Specific Storativity;

o $t$ : Time;

o $W$ : Vertical flow per unit volume.

The geometry and boundary conditions are generally complex. Analytical methods are rarely applicable for determining a closed form solution of the partial differential equation [17]. The diffusivity equation was solved using a finite element approximation technique. The first step for the application of this method was the discretisation of the modelled area into small grid form using Feflow 7.0 modelling code [18]. This code is widely used in the mining industry and particularly in mineral sand dredging operations. It is able to manage and process a large amount of data and to produce a high level of accuracy requested by the mine.

For mass balance calculations, in addition to this general equation of diffusivity, the following parameters described below are requested [19]:

- Mass flow rate of water (in $\mathrm{t} / \mathrm{h}$ or $\mathrm{m}^{3} / \mathrm{h}$ ): $Q_{W}=\left(\frac{M \times 100}{C_{w}}\right)-M$

- Pulp volume flow (in $\mathrm{m}^{3} / \mathrm{h}$ ): $Q=\frac{M}{S}+M\left(\frac{M-C_{W}}{C_{w} \times S_{L}}\right)$

- Pulp density (in $\left.\mathrm{t} / \mathrm{m}^{3}\right): S_{M}=\frac{S \times S_{L}}{S-\left(C_{W} \times \frac{S}{100}\right)+\left(C_{w} \times \frac{S_{L}}{100}\right)}$

- Solid volume percentage (\%) of the pulp: $C_{V}=100 \times \frac{S_{M}-S_{L}}{S-S_{L}}$ With,

o $M$ (tph), Mass flow of dry matter to be pumped

o $C w(\%)$, Percent solid pulp by weight

o $S\left(\mathrm{~T} / \mathrm{m}^{3}\right)$, Solid density

o $S L\left(\mathrm{~T} / \mathrm{m}^{3}\right)$, Liquid density

From the tests carried out in the mineralogical laboratory, the solid density equals to 2.65 .

\section{Conceptual Model}

The modelled domain extends along the coastal line for a length of $55.5 \mathrm{~km}$ and an average width of $15 \mathrm{~km}$. The surface area is $848 \mathrm{~km}^{2}$.

The Figure 10 presents a 2D conceptual model focused on the dredge channel and tailings where flow patterns are synthesized.

In this model, we consider mainly the quaternary shallow aquifer since no natural flow exchange with the deep Maastrichtian aquifer occurs. 


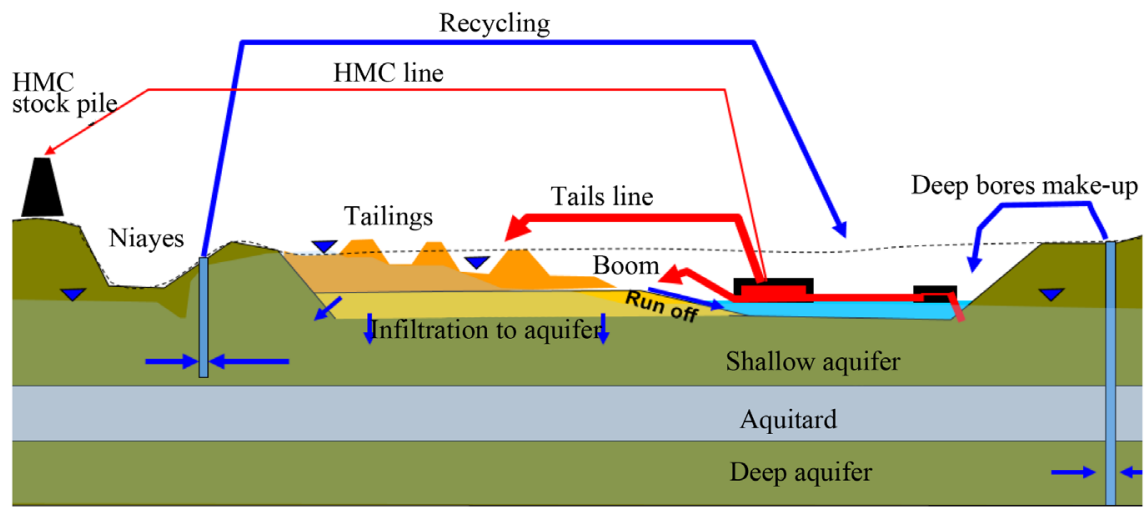

Figure 10. Schematic of the conceptual operating model of GCO mine [20], modified.

The model is limited to the upper aquifer which average thickness is $40 \mathrm{~m}$ in the orebody and $60 \mathrm{~m}$ in the continental zone. The most important flux exchanges take place between the system dredge pond/tailings and the aquifer. Inputs to the aquifer are infiltration, inflow through the edge pond, outflow to the edge pond, recycling pumping, irrigation and pumping from the deep aquifer.

The boundary conditions are defined as followed:

- A Dirichlet (constant water level) boundary condition (h zero) to the western ocean limit,

- A groundwater mound crest line to the East set as variable head boundary condition (Dirichlet type) from $+25 \mathrm{~m}$ in the south at Taïba Ndiayeto $+5 \mathrm{~m}$ at Bendiouga (north).

- A no flow boundary is the south representing the piezometric mound from west to east of Tivaouane and a $2^{\text {nd }}$ no flow Boundary applied to the impervious bottom aquifer varying between 5 to $10 \mathrm{~m}$.

- A no-flow boundary in the northern limit is applied using groundwater flow pattern parallel to this limit.

- The dredge pond and tailings are set as Cauchy type as it is functioning like a river. The dredge pond with the tailings storage is about $1.5 \mathrm{~km}$ long. The deposits of slimes (peat or clay) at the bottom of the pond constitute a layer with very low hydraulic conductivity. This semi-permeable layer then allows vertical flow exchange which will regulate the water flows between the pond and the aquifer. The flows exchanges depend also on the water level in the dredge pond and in the tails.

\section{Input Data}

Initial head conditions are set to be the water level recorded in Dec 2012 and to better take into account the anisotropy of the system, the one-layer aquifer was subdivided vertically into 3 sub-layers and 4 slices representing:

- the piezometric surface for slice 1 ;

- The sea level for slice 2;

- The top of shallow bore screens for slice 3; 
- The bottom aquifer for slice 4 .

In addition to the 3 layers set, the domain is divided in two zones located west and east. This spatial difference is set to account for differences between the Aeolian sand (ore) and the continental sand. Following several calibration trials manually and automatic using FePEST, the following hydraulic conductivities and effective porosity represent calibrated values (Table 2).

This variability in $\mathrm{K}$ values is derived from characteristics between the orebody sand at the west and the continental sand at the East while differences in $\mathrm{Kz}$ values reflect clayey peat and clay interlined contents occurrence in the different layers.

Other input are the pumping rates data of the 48 recycling bores ("Containment bores") located along the active mine path (Figure 11) with average pumping flow of $30 \mathrm{~L} / \mathrm{s}$ (Table 3 ) and the 22 shallow boreholes for local population water supply.

\section{Results and Discussions}

\subsection{The Water Model Calibration in Transient State}

Given the continuous decrease of the sand quaternary aquifer since 1970s [10] [21], the farmlands irrigation and the new stresses from GCO mining operations, the transient model simulation is required. Obviously, transient models are more important tool than models simulated under steady state conditions for groundwater management that leads sustainable utilisation of the resource [22]. The calibration period runs from 2007 to November 2014 and difference between simulated and measured head values shows a fair match (Figure 12) with the exception of 12 control points which exhibit above $\pm 1 \mathrm{~m}$ confidence interval.

Computed Mean error $(\bar{R})$, mean absolute error $(|\bar{R}|)$, Standard Error of

Table 2. Tables of hydrodynamic parameters.

\begin{tabular}{ccccccc}
\hline \multirow{2}{*}{ Parameters } & \multicolumn{2}{c}{ Layer 1 } & \multicolumn{2}{c}{ Layer 2 } & \multicolumn{2}{c}{ Layer 3 } \\
\cline { 2 - 6 } & West & East & West & East & West & East \\
\hline $\mathrm{Kx}(\mathrm{m} / \mathrm{d})$ & 1.00 & 1.00 & 17.00 & 13.80 & 20.00 & 1.00 \\
$\mathrm{Ky}(\mathrm{m} / \mathrm{d})$ & 1.00 & 5.53 & 16.69 & 12.00 & 20.00 & 1.33 \\
$\mathrm{Kz}(\mathrm{m} / \mathrm{d})$ & 0.14 & 11.72 & 0.36 & 3.00 & 0.05 & 1.58 \\
$\mathrm{SY}$ & 0.28 & 0.28 & & & & \\
\hline
\end{tabular}

Table 3. Summary of the 48 eastern containment bores infrastructures performance.

\begin{tabular}{cccccccc}
\hline ID Forage & SWL & $\begin{array}{c}\text { Aquifer } \\
\text { bottom }\end{array}$ & Thickness & Flow & $\begin{array}{c}\text { Dynamic } \\
\text { level }\end{array}$ & Draw down Specific flow \\
\hline & m. IGN & m. IGN & $(\mathrm{m})$ & $\mathrm{m} 3 / \mathrm{h}$ & $\mathrm{m} . \mathrm{IGN}$ & $(\mathrm{m})$ & $\mathrm{m}^{3} / \mathrm{h} / \mathrm{m}$ \\
Min & +5.01 & -44.50 & 24.70 & 39.60 & -23.47 & 4.15 & 1.99 \\
Moy & +5.87 & -30.66 & 36.53 & 113.50 & -11.26 & 17.13 & 7.56 \\
max & +7.29 & -17.61 & 50.39 & 165.60 & +1.85 & 29.56 & 21.80 \\
\hline
\end{tabular}




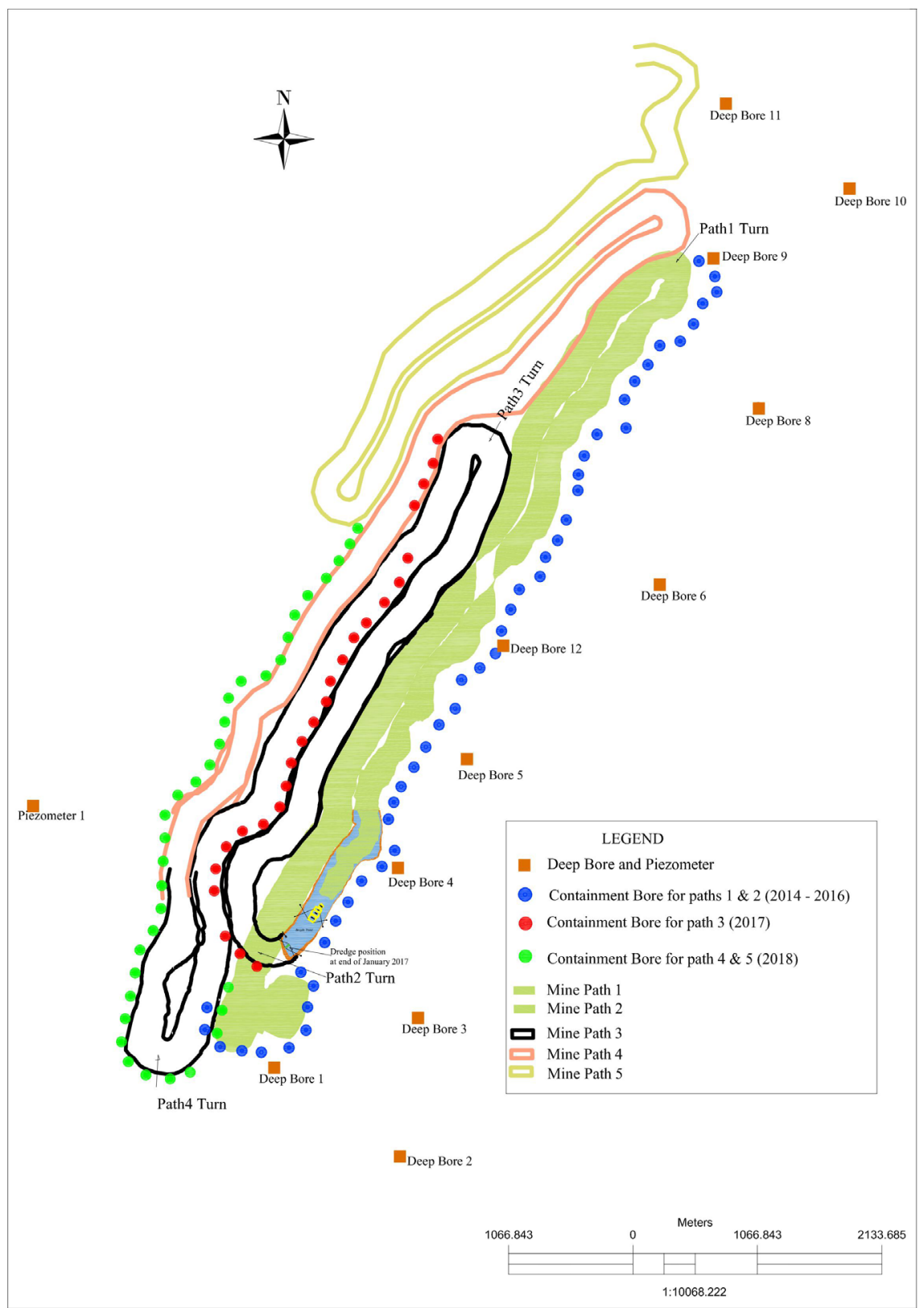

Figure 11. Localization map of the containment bores.

Estimate (SEE), Root Mean Squared Error (RMSE) and NRMSE with values of less than $1 \mathrm{~m}$ together with the square of the Pearson correlation coefficient of 0.88 indicate a relatively fair match (Table 4 and Figure 13).

The computed Water budget for April 2014 (Table 5) evidenced the following features:

- Inflow from the east boundary is $7,036 \mathrm{~m} 3 / \mathrm{d}$;

- Outflow to the sea is 4 times higher;

- An evapotranspiration loss of $45,261 \mathrm{~m}^{3} / \mathrm{d}$;

- Low pumping from Community need of $5,988 \mathrm{~m}^{3} / \mathrm{d}$;

- Aquifer storage of $72,534 \mathrm{~m}^{3} / \mathrm{d}$. 


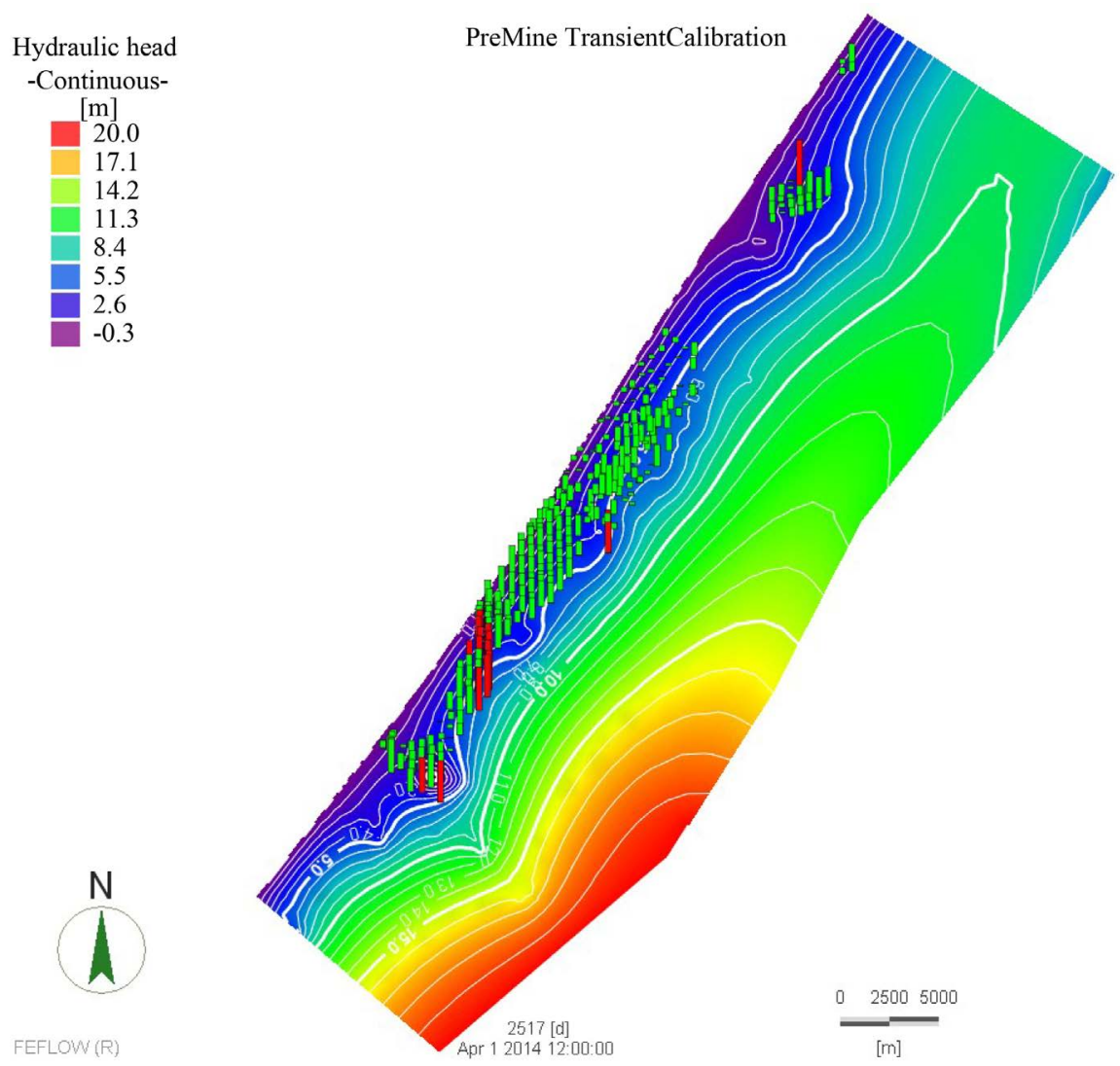

Figure 12. Analysis of the calibrated piezometric levels by transient model.

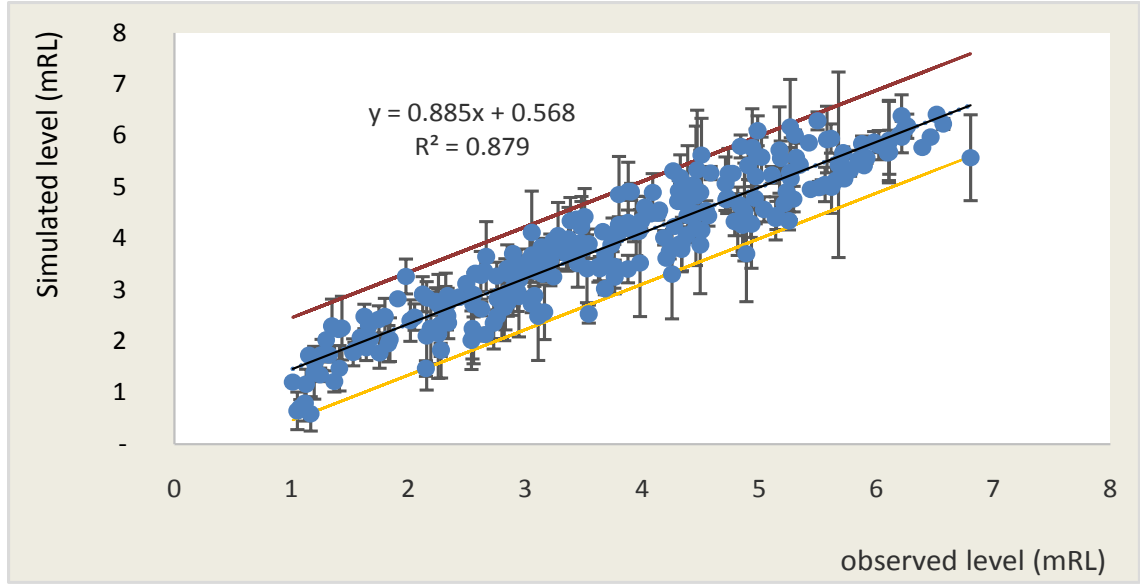

Figure 13. Correlation of measured and calculated values.

Table 4. Analysis of the differences in the calibration results of the model.

\begin{tabular}{ccc}
\hline Errors & Symbol & Values \\
\hline Mean error $(\mathrm{m})$ & $\bar{R}$ & 0.14 \\
Mean absolute error $(\mathrm{m})$ & $|\bar{R}|$ & 0.44 \\
Standard error of estimate $(\mathrm{m})$ & SEE & 0.50 \\
Root mean square error $(\mathrm{m})$ & RMSE & 0.52 \\
\hline
\end{tabular}


Table 5. Water balance in transient state.

\begin{tabular}{cc}
\hline TERMS & FLOWS $\left(\mathrm{m}^{3} / \mathrm{d}\right)$ \\
IN FLOW & 7,036 \\
Dirichlet BCs & 72,534 \\
Storage release & $\mathbf{7 9 , 5 7 0}$ \\
Total Inflows & \\
OUT FLOW & 29,107 \\
Dirichlet BCs & 5,988 \\
Wells (Community) & 45,261 \\
Evapotranspiration & 88 \\
Storage capture & $\mathbf{8 0 , 4 4 4}$ \\
Total Outflows & \\
\hline
\end{tabular}

\subsection{Water Model Update and Validation}

The initial water model calibrated based on the pre-mine condition was reviewed taking account the 1 Year operational data from May 2014 to July 2015. The data include the dredge pond water level variation, the daily production and the containment bores pumping.

\subsubsection{The Dredge Pond, the on-Path Tails and the Production Records}

During the two first mining paths, the dredge pond was maintained at the static water table. Inflows are assumed to balance outflows. For the following years, when the pond level has been raised from +2 to $+4 \mathrm{~m}$, other losses occur across the pond edges. During the process, a slime layer of $7.5 \mathrm{~cm}$ at the bottom of the dredge was set as semi impervious layer due to the fact that fine grains discharge directly into the dredge pond through overflow. In addition, the groundwater mound inferred by the pond is also taken into account as well as make-up water from the deep aquifer to achieve the required water level.

The pond level and the feed sand extracted are monitored on a daily basis (Figure 14). An optimal range of pond water level variation was set along the mine path with lower limit and upper limit. These levels depend on the piezometric data, the height of the dunes and the depth of the high mineral concentration.

The data were implemented in the model as well as the makeup water from the recycling bores and Maastrichtian boreholes. Figure 15 shows the impact of the recycling bores pumping on the aquifer water level in the surrounding area.

The containment bores pumping records in the vicinity of the mine path have been integrated into the water model.

\subsubsection{Water Model Validation in Diogo Area}

The model has generated the piezometry below that was used in the validation test (Figure 16): 


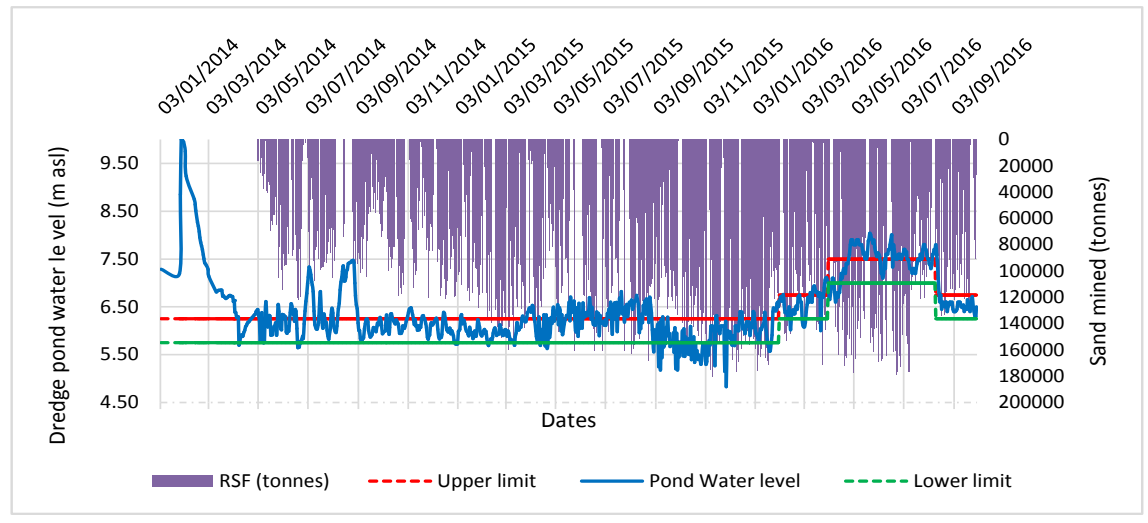

Figure 14. Variation of the pond water level versus the daily feed sand produced.

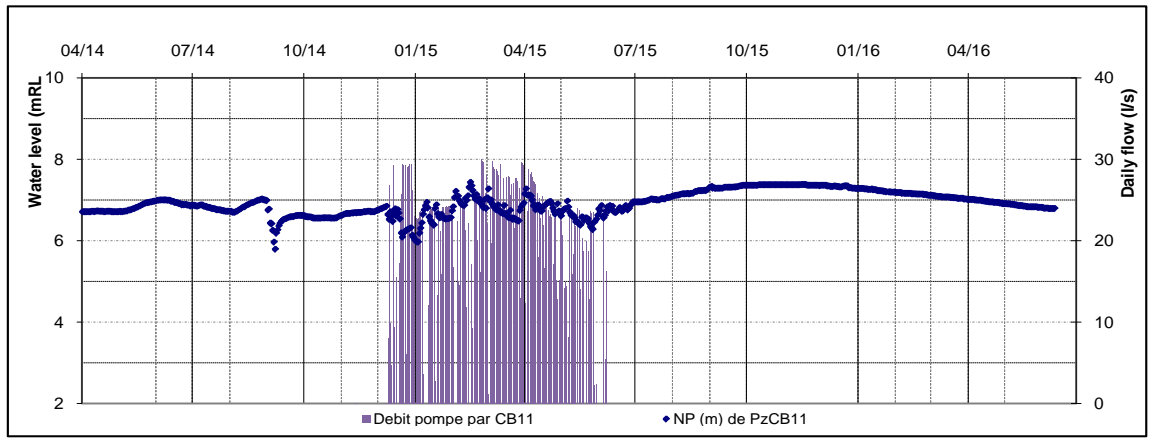

Figure 15. Daily chronicle of pumped flows (CB) and piezometric levels (PzCB11).

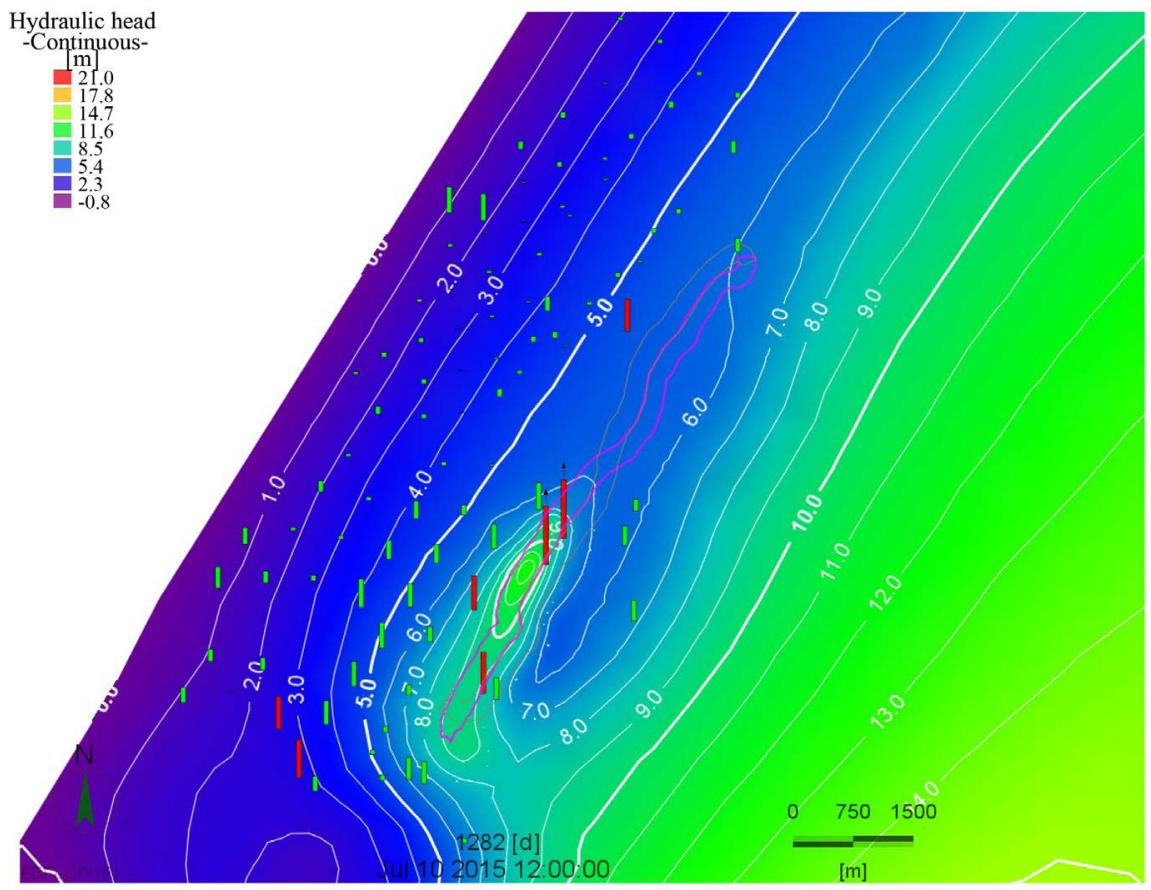

Figure 16. The computed water levels one year after the mine started (July 2015).

The results show a good match between measured and computed head values at the exception of 7 piezometers out of 95 . Head computed values in piezome- 
ters D022 and D023 are high computed by 1.25 and $1.11 \mathrm{~m}$, respectively corresponding to a local mound inferred by tailings piles.

\subsubsection{Statistical Analysis}

From a detailed statistical point of view, the precision results are presented below (Table 6).

The smallest RMSE is 0.29 evidenced a better accuracy of the model considering only the Diogo area. The Normalised root mean square error (NRMSE) of $4.17 \%$, is well below the indicative precision threshold of $10 \%$ [23]. The graph below shows the correlation line between measured and computed values.

The dispersion of the results is represented as a regression associated with a confidence interval of $\pm 0.5 \mathrm{~m}$ (Figure 17). The square of the Pearson correlation coefficient is 0.98 .

\subsection{The Water Model Predictions from February 2017 to November 2020}

After the validation step, the model is used for simulation purposes, from February 2017 to November 2020 (Figure 18), to plan mining operation in the short and medium term and determine water need to maintain the requested pond level.

Table 6. Analysis of the accuracy of the calibration result of the model in production phase.

\begin{tabular}{ccc}
\hline Errors & Symbol & Values \\
\hline Mean error $(\mathrm{m})$ & $\bar{R}$ & 0.004 \\
Mean absolute error $(\mathrm{m})$ & $|\bar{R}|$ & 0.20 \\
Standard error of estimate $(\mathrm{m})$ & SEE & 0.26 \\
Root mean square error $(\mathrm{m})$ & RMSE & 0.29 \\
Normalised Root mean square error $(\%)$ & NRMSE & 4.17 \\
\hline
\end{tabular}

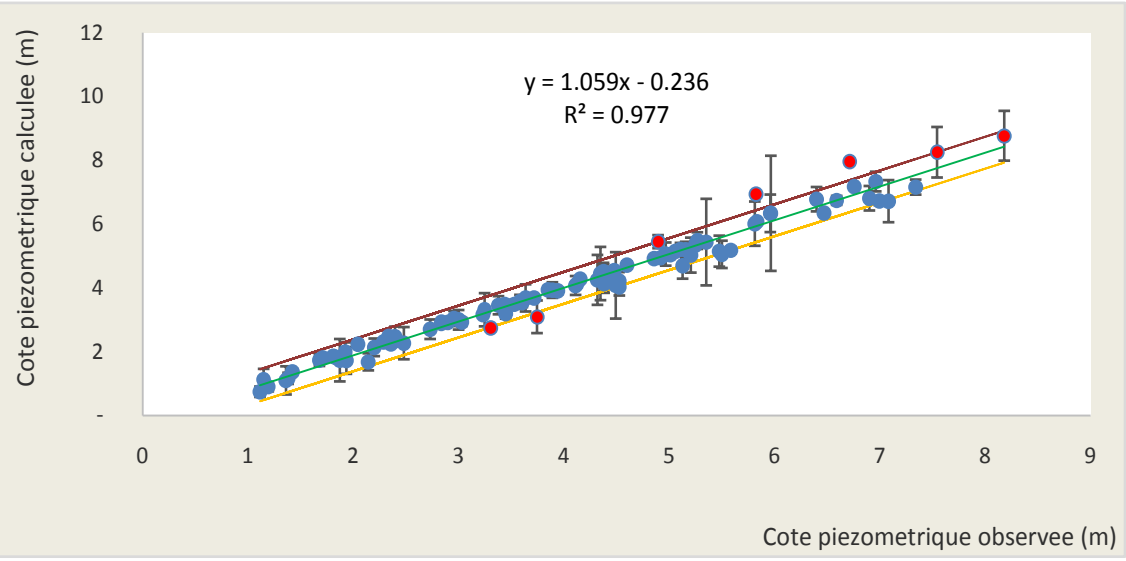

Figure 17. Correlation line between measured and calculated values during production phase. 


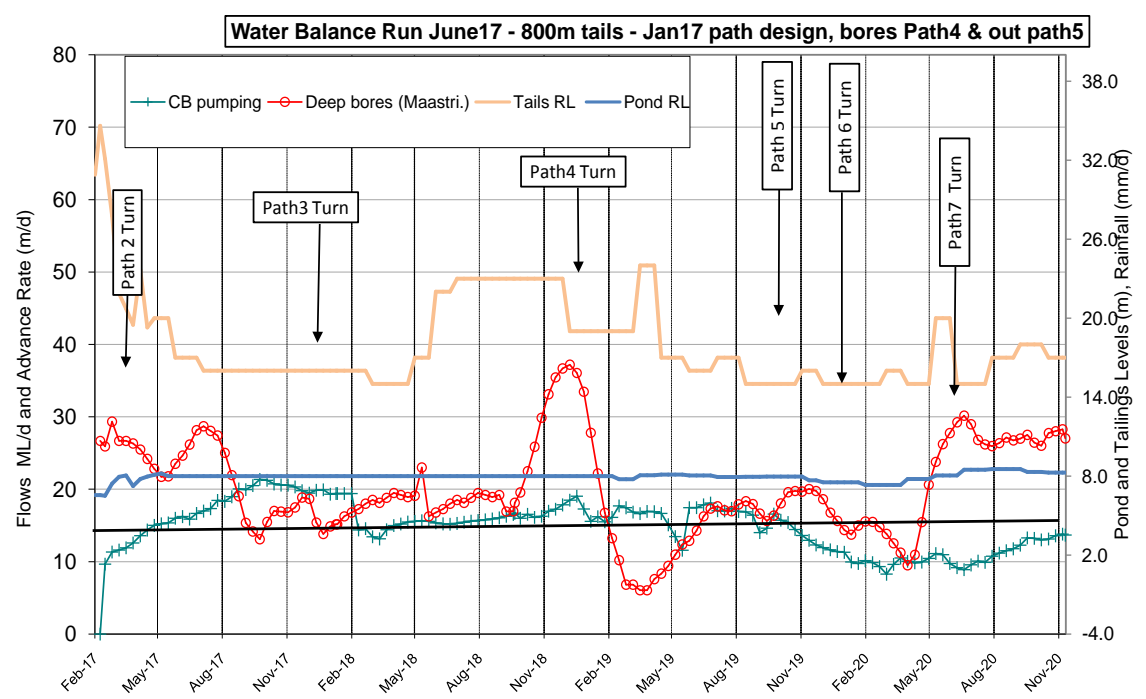

Figure 18. The variation of the forecast water balance for the coming 4 years period from February 2017.

During this operation period, the dredge will cross the dune areas at variable altitudes. The high dunes have their ground level at $+26 \mathrm{~m}$ and the low dunes are about $+14 \mathrm{~m}$ to $+16 \mathrm{~m}$.

The higher dunes are crossed by the pond from February to May 2017 and the next stages will occur from May 2018 to May 2019. At the high dunes, the dredge pond advance is low with an average of 16 meters per day.

The water losses of the operating system (pond and tails) which is the key of the mine water balance vary between $14,000 \mathrm{~m}^{3} / \mathrm{d}$ and $49,000 \mathrm{~m}^{3} / \mathrm{d}$. To maintain the pond at the optimum water level, the water loss is compensated by the recycling pumping and the deep bores extraction. For most of the period, the recycling pumping would be around $16,000 \mathrm{~m}^{3} / \mathrm{d}$ before decreasing to $10,000 \mathrm{~m}^{3} / \mathrm{d}$ from November 2019. Thus, the contribution of the Maastrichtian aquifer will be variable and almost follow the total water losses trend. The yearly pumping trend is as follow:

- 22,000 m³/day from Feb 2017 to December 2017;

- $20,000 \mathrm{~m}^{3} /$ day for 2018 ;

- $16,000 \mathrm{~m}^{3} /$ day for 2019 ;

- $22,000 \mathrm{~m}^{3} /$ day for 2020 .

In addition, there is an increase of $6000 \mathrm{~m}^{3} / \mathrm{d}$ on the yearly demand, from 2019 to 2020, which corresponds to the mining of Diogo northern area where the groundwater level is as low as RL5 $\mathrm{m}$ for a requested pond level of RL8 $\mathrm{m}$.

The lower requested make-up water becomes higher from July to August 2017. The peak would be reached at $43,000 \mathrm{~m}^{3} / \mathrm{d}$ in January 2019. This increase is mainly due to:

- The Fass Boye zone mining where the SWL is RL6 m;

- Dredge pond water level rise from $+6 \mathrm{~m}$ to $+8 \mathrm{~m}$;

- This period dry season period; 
- The dredge passing through the higher dunes.

The average recycling water for the 4 years' period is $15,000 \mathrm{~m}^{3} /$ day representing a contribution varying between $40 \%$ to $48 \%$ of the total dredge pond make-up water.

\subsection{Discussions and Conclusions}

The water demand for the 4 years mine period modelled could be ensured by pumping from both aquifers: recycling lost water from the tails and pumping from the deep Maastrichtian aquifer. The largest yearly average makeup water for the dredge pond of $37,000 \mathrm{~m}^{3} /$ day with a peak of $49,000 \mathrm{~m}^{3} /$ day can be supplied from the recycling and the deep bores makeup water with the recycling contributing between $40 \%$ to $48 \%$.

For the shallow aquifer, the water level remains +2 meters above the static water table (SWT) since the mining started despite the recycling pumping process. Therefore, climate change will cause sharp increases in temperature, which in turn, is likely to affect evapotranspiration and atmospheric water storage, thereby potentially changing the magnitudes, frequencies, and intensities of rainfall, as well as its seasonal and inter-annual variabilities [24]. Hopefully, based on the continuous makeup water from the deep aquifer, the upper aquifer water level in the vicinity of the mine will continue to be above the SWT.

Conversely, the confined deep aquifer which is ensuring the dredge pond make up water between $52 \%$ and $60 \%$ is continuing to be depleted as the system is confined and the main recharge area is located at the SE of the sedimentary basin.

Recent study by the Water Ministry [25] evidenced drawdown between 7 and 13 meters prior GCO pumping for pond makeup water. This is problematic given that the freshwater aquifer is delimited in its eastern part by the central salt water band located $30 \mathrm{~km}$ away. For sustainable use of the groundwater resources, continuous update of the hydraulic model and water level monitoring should be promoted to maximise recycling and reduce pumped makeup water from the Maastrichtian aquifer.

In the next few years, the mine paths will move closer to the shoreline. So, much more attentions should be paid to the piezometric monitoring and hydro chemical measurements of the coastal strip to detect any risk of saline intrusion.

\section{References}

[1] Sane, M. (2015) Notes sur les Ressources en euax du Senegal: Zones potentielles pour le transfert d'eau. Ministere de l'Hydraulique du Senegal, Dakar.

[2] ISRA (1996) Rapport Annuel. DAKAR.

[3] Dryade (1990) Inventaire Biophysique de la région des Niayes Synthèse, document de recherche dans le cadre du Project Conservation des Terroirs du Littoral, Ministère du Développement Rural et de l'Hydraulique, DFCCS. Republique du Senegal, Dakar, $262 \mathrm{p}$.

[4] TROPICA (2005) Etude d'impact environnemental et social (EIES) du Projet Zircon 
de la Grande Cote. 92-93.

[5] Faye, S., Diaw, M., Ndoye, S., Malou, R. and Faye, A. (2009) Impact of Climate Change on Groundwater Recharge and Salinisation of Groundwater Resources in Senegal. Groundwater and Climate in Africa, Kampala, June 2008, 163-173.

[6] Kane, A. (1985) Le bassin du Sénégal à l'embouchure Flux continentaux dissous et particuliaires. Invasion marine dans les vallées du Fleuve. Thèse doct, 3ème cycle, Trav. Lab. geogr. Phy. Univ. de Nancy II, Dakar, 186 p.

[7] Michel, P. (1973) Les bassins des fleuves Sénégal et Gambie. Etude géomorphologique. Mém. ORSTOM. N63, 3 tomes, Paris, 752 p.

[8] Michel, P. (1956) Rapport préliminaire sur la géologie de la région des Niayes, de Kayar à l'embouchure du Sénégal. Rapport inédit MAS.

[9] Puttalaz, J. (1962) Hydrogéologie de la région des Niayes. Rapport DAK 62-A12, 37 p.

[10] Noel, Y. (1978) Etude hydrogéologie des calcaires lutétiens entre Bambey et Louga (2ème phase). BRGM, Orleans, $100 \mathrm{p}$.

[11] Kaba, M., et al. (2016) Spatial and Seasonal Variability of Groundwater Hydrochemistry in the Senegal North Littoral Aquifer using Multivariate Approach. Environment Earth Sciences, 75, 274. https://doi.org/10.1007/s12665-016-5520-x

[12] MDL (2010) Grande Cote Operations-Definitive Feasability Study: Engineering and Technical. GCO, Senegal.

[13] Herchenchorn, W., et al. (2006) From Heavy Minerals Mining to a Wet Dredge Mining Operations. In: Proceedings of the World Dredging Congress, Papers and Presentations, TIB Leibniz Information Centre for Science and Technology, 1, 129-140.

[14] Consolidated Rutile Limited (CRL) (2010) How Are Mineral Sands Mined on North Stradbroke Island?

[15] Associates, G. (2007) Snapper Mineral Sands Project Environmental AssessmentHydrogeological Assessment. Bemax Resources Limited, Mildura.

[16] De Marsily, G. (1986) Quantitative Hydrogeology. Academic Press, Paris.

[17] Mondal, N.C., Singh, V.P. and Sankaran, S. (2011) Goundwater Flow Model for a Tannery Belt in Southern India. Journal of Water Resource and Protection, 3, 85-97.

[18] Diersch, H.-J.G. (2005) FEFLOW Software-Finite Element Subsurface Flow and Transport Simulation System-Reference Manual. WASY GmbH, Berlin.

[19] Grzina, A., et al. (2002) Slurry Pumping Manual. A Technical Application Guide for Users of Centrifugal Slurry Pumping Systems. Warman International Ltd.

[20] Robertson, M. (2013) Groundwater Assessment. Path 1-4 Tailings and Water Management. Grande. Grande Cote Operations (GCO).

[21] Faye, S. (1995) Modélisation hydrodynamique des nappes du littoral nord entre Cayar et St-Louis. Impact des futurs prelevements envisages dnas le cadre de l'approvisionnement en eau de Dakar et de ses environs. These de 3e cycle, UCAD, Dakar, $167 \mathrm{p}$.

[22] Berehanu, B., Ayenew, T. and Azagegn, T. (2017) Challenges of Grundwater Flow Model Calibration using Modflow in Ethiopia: With Particular Emphasis to the Upper Awash River Basin. Journal of Geoscience and Environmenent Protection, 5, 50-66. https://doi.org/10.4236/gep.2017.53005

[23] Lalot, E. (2014) Analyse des signaux piezometriques et modelisation pour l'evaluation quantitative et la caracterisation des echanges hydrauliques entre les aquiferes allu- 
viaux et rivieres-Cas du Rhone. Ecole Nat. Superieure des Mines de Saint Etienne.

[24] Shahid, S., Alamgir, M., Wang, X.-J. and Eslamian, S. (2017) Climate Change Impacts on and Adaptation to Groundwater. Researchgate, 107-123. https://doi.org/10.1201/9781315226781-7

[25] GKW Consult (2009) Modélisation numérique-Littoral Nord, Rapport Phase IV. Lot 1B. Projet Eau à Long Terme, Republique du Senegal, Senegal. 